\title{
Representations of Children's Voices about Their Health in Social Services Arguments in Support of Their Decision
}

\author{
Elin Hultman ${ }^{1} \&$ Ann-Christin Cederborg ${ }^{2}$ \\ ${ }^{1}$ The Swedish Institute for disability research/ Department of Behavioural Sciences and Learning, Linköping University, \\ Linköping, Sweden \\ ${ }^{2}$ Department of Child and Youth Studies, Stockholm University, Stockholm, Sweden \\ Correspondence: Elin Hultman, The Swedish Institute for disability research/ Department of Behavioural Sciences and \\ Learning, Linköping University, S-581 83Linköping, Sweden.
}

\author{
Received: November 1, 2013 Accepted: November 14, 2013 Available online: January 25, 2014 \\ doi:10.11114/ijsss.v2i2.265 \\ URL: http://dx.doi.org/10.11114/ijsss.v2i2.265
}

\begin{abstract}
Research points to the importance of involving children in social investigations, since their perception of their own situation and needs may differ from what others take to be the case. There is however no specific recommendation of how children's voices should be inscribed in such investigations. This study explores if and how children's voices are represented in the final part of the social investigations where social workers argue in support of their decision. It has a specific focus on how children's voices about their health are included when, at the point of initiating an investigation, concerns have been raised about their physical and psychological well-being. Inspired by a social constructionist and discursive analytical approach we analyzed 60 arguments in as many social investigations. The findings are that children's psychological-, physical health or general well- being was mentioned in 46 of the 60 argumentations. The child's own thoughts about his or her health were represented in 12 of these 46 arguments. Instead, children's health was mostly represented by referrals to other persons. In those 12 arguments where children's views are presented they were reported in different ways. Their view could, for example, be sparingly reported and be used in order to confirm a previous statement or opinion. Two of the cases go more into details about what the children actually have said about their health. We conclude that if the representation of the child's own voice is excluded it is difficult to understand if and how children's perspective of their health has been taken into consideration in the decision process.
\end{abstract}

Keywords: social welfare investigations: social workers arguments for decision: children's voices about their health

\section{Introduction}

Since Sweden's ratification of the UN Convention on the Rights of the Child (UNCRC) 1989, the child's position within the social services has gained a certain perspicuity (Sundell, Egelund, Andrée Löfholm \& Kaunitz, 2008; Leviner, 2011). The Convention proffers that children's best interest is always to be taken as a primary consideration in all activities affecting them, regardless of whom or which institution is involved (3:1 UNCRC). Furthermore, the convention states the specific right that children should be able to freely express their own views on questions directly affecting them, with these views being given due weight in accordance with both age and maturity (12:1 UNCRC).

These guidelines are included in the Swedish social services Act (SoL 2001:453) also, which proclaims the importance of always paying particular attention to what is best for children ( $\operatorname{SoL} 1: 2$ ) as well as giving them the opportunity to express their opinions. In case children do not state their view, social services should try to clarify their opinion in other ways (11:10). If the child is mature enough his or her opinion should be given due weight (12:1 UNCRC; SoL 11:10). It is from the age of 15 that children should also give their consent about decisions of support and protection (§ 1 Special provisions for Care of Young People Act (LVU) 1990:52). In addition, social services have the possibility of talking to children without permission from, or without the presence of, their guardians (SoL 11:10).

In the context of the social services this means that one can identify two dimensions in the directives as to how the child should be brought into focus. On the one hand, social workers have to assess what is deemed to be in the child's best interest (SoL 1:2; UNCRC 3:1). Yet, the child's own perspectives about his or her immediate situation should be clarified and thus be taken into account (SoL 11:10; UNCRC 12:1). However, if social workers do not follow recommendations to listen to children, those children can never appeal against not being heard or involved in the 
process (Leviner, 2011).

In coming to a final decision about the child's best interest the child's own wishes have to be assessed in relation to, inter alia: one, the parent's capacity and view; two, aspects of the child's surrounding as well as, three, informed opinion from professionals and persons close to the child (National Board of Health and Welfare, 2012). What is documented in the investigation should throw light upon the specific situation of the child, even though it cannot provide a full and exhaustive picture of the child's situation. What is disclosed should be seen as a summary about the child's present and previous circumstances. The arguments provided to support the decision should however give answers to the question stated in the beginning of an investigation and is meant to clarify the process by which a social worker has come to a decision about a child's needs (National Board of Health and Welfare, 2006).

When an initial concern is raised about children's health it is of importance that an argument regarding the health needs of the particular child be included when recommending support. This is because children's health is a significant factor in ascertaining their overall well-being. Children's biological and psychological conditions can influence their social situation, and, concomitantly, social conditions can impact upon the health of children (Andershed, Andershed, \& Tuvblad, 2013; Lundberg, Åberg Yngwe, Kölegård Stjärne, Björk \& Fritzell, 2008). Moreover, physical impairment can influence psychological health (Garralda, 1994; Rangel, Garralda, Hall \& Woodham, 2003) while psychological aspects, such as stress, can influence the physical reaction of the body (Ljung \& Friberg, 1994). Furthermore psychological problems tend to increase the risk of accidental injuries (Wan, Morabito, Khaw, Knudson \& Dicker, 2006). However, while considering all of the above, health development and the consequences of health conditions will invariably be influenced by each unique child's individual conditions (Heinonen, Metteri, \& Leach, 2009; Sarafino, 2006) as well as their social and cultural environment (Gironda et al., 2006; Park et al., 2009; Power \& Kuh, 2006; Robertson, Brunner, \& Sheiham, 2006; Shaw, Dorling \& Smith, 2006). Hence, to be able to understand the potential for positive development, as well as the need for support, it is necessary to make an analysis of each child's situation (James, Jenks \& Prout, 1998). Children can also have individual experiences of their interests and needs. This means that accounting for the individual child's own opinion is crucial before a final decision about their particular needs is made (Meadows, 2010; James \& Prout, 1997; James et al., 1998).

It has previous been shown that the social services seldom include children in decision-making processes. Even on those occasions where children have been said to be included in the process, questions can be raised as to what this inclusion has meant in practice. For instance, rarely were children properly involved in the meetings within which the decisions were made (Thomas, 2002). It has also been found that children themselves were rarely interviewed about their own experiences (Cederborg \& Karlsson, 2001). Furthermore the child's perspective was often absent in the written reports (Mattsson, 2002) or, if it was present, then the views of the child were represented differently depending on the consistency of these views with the decision-maker (Thomas \& O'Kane, 1999). The perceived vulnerability of children has also been found to merely be the result of the adult's construction of the child (Egelund, 1997). Subsequent studies have also shown that even though social workers have become more likely to have contact with the child under investigation (Sundell et al., 2008) participation could mean different thing for children and social worker (Gallagher et al., 2012; Mason 2008). Finally, there is an indication that children's individual situation and needs are described by knowledge offered from other persons (Egelund, 1997; Hennum, 2011; Mattsson, 2002 ) and even when children's perceptions of themselves are included in the descriptions of their life situation the reporting of their opinions may be limited (Hultman \& Cederborg, 2013).

\section{Aim}

Research points to the importance of involving children in social investigations, since their perception of both their own situation and needs may differ from the views offered by others (Alanen, 1994; Andersson Aronson, Hessle, Hollander \& Lundström, 2001; Gleason \& Evans, 2004; Hollander, 2001; Mason, 2008). In addition, there is no specific description as to how children's voices should be inscribed in social welfare investigations. Therefore, this study explores if and how children's voices are represented in the final part of the social investigations, in which social workers justify their decisions. The study specifically explores how children's voices about their health are included when initial concerns were raised surrounding their health.

\section{Data}

This study is part of a larger project exploring how social workers focus on children and children's health in written investigations. The investigations have, in this larger project, been gathered from a middle-sized town in Sweden, and included 272 investigations conducted by the social services during 2008. These investigations concerned children between the ages of 0 and 18 years. The children were investigated according to Chapter 11, $\S \S 1$ and 2, of the Swedish Social Service Act (2001:453) in response to the submission of a report by the social services. Both parent- and child-related reports about the child's life situation were included. Since we were interested in investigations where 
someone outside the family had experienced concerns for the child, reporting this independently to social services, we decided to exclude applications from children and their families related to self-defined need of support.

For the purpose of this study special attention is given to investigations where social services stated that the reason for conducting an investigation was distinct worries about the child's health. Out of a possible 272 cases, the sample comprised of 60 arguments in as many social investigations. There were, however, a total of 59 children, since one girl was subject to investigation twice under the same period. The 59 children assessed were composed of 29 girls and 30 boys. The children were between 4-17 years ( $M=12.7$ years) when the investigations were conducted. Here, we have opted to study those aspects of the investigative reports that social workers name 'analysis' and 'assessment', that is to say, those passages in which the social workers present the individual child's circumstances and seek to justify the decisions reached.

\section{Ethical Considerations}

The project was approved by the Regional Ethical Committee in Linköping, Sweden (Dnr 221-08). Details and references to persons and places that might enable identification have been removed. In the excerpts, the child's name is referred to as X. Names of other persons or places are explained in brackets. Expressions that are not of importance to the points being made have been removed from the excerpts. This is shown with the use of elliptical marks [...].

\section{Theoretical Orientation}

The analysis takes as its point of departure a discourse analytic inspired approach. Such a theoretical orientation has particular relevance here in inquiring into how descriptions of phenomena are made and the processes by which such descriptions are stabilised and deemed accurate. Whether the description seems credible or not will be contingent upon the words that are used and how the meaning of these words is constructed (Potter, 1996). In addition, the descriptions made should be analysed in their situated context as how language is used in the process of describing, representing or declaring something reflects understanding within a specific context (Potter 1996; 2005; Potter \& Wetherell, 1995). This understanding may therefore also influence how people act in a certain context (Potter, 2003), which implies that the descriptions used might influence the decisions issued by the social workers. Furthermore, the analysis proceeds from the basis that the written arguments are influenced by how the social workers understand their function and their role in the organisation as well as how they might be influenced by the existing administrative frames of the social services (Hall, 1997).

In a study of documents like social investigations, we don't know whether the social worker's representation of the child's voice is correct or whether the description of the child's health is accurate. Our focus is on language, on its uses and its possible effects.

\section{Analytical Procedure}

Inspired by Potter \& Wetherell (1987) the analytical focus was on language use when social workers described children's views about their own health situation. We searched for patterns of variation and consistency in the structure of the social workers' accounts.

To begin, the first author selected all sentences in which support for social workers' decisions were laid out in terms of children's psychological-, physical health or well- being. We chose both specific references to health conditions but also descriptions of these health aspects in a more general manner. Second, accounts in which social workers referred to children's opinions were identified. Once the relevant passages were selected, repeated readings of them were carried out. This was done in order to identify both similarities and differences in language use between reports. The findings were then discussed between the two authors, who collaboratively organised the data into themes that could help to explain the questions posed by this study. During this process the chosen themes were reread, on the basis of which some themes were rejected, with new themes emerging. The results presented below are the main findings of this analytical process and the most representative examples have been selected for each theme.

\section{Findings}

Children's health was mentioned in 46 of the 60 argumentations, and such references were commonly couched in terms of psychological-, physical health or general well- being. The child's own thoughts about his or her health were represented in 12 of these 46 arguments. This means that, ultimately, children's voices were absent in most of the reports. Instead, children's health was mostly represented by referrals to other persons.

\subsection{Lack of References to the Child's Voice}

When there were no references to a child's views the social workers could describe their health by reporting on what others had to say. Such statements could also have either no clear sender or reports children's behaviour alone. 


\subsubsection{References to Professionals or Parents}

Adults - such as, the parents, a member of the school staff or, in some cases, experts from Child and Youth psychiatric institutions - were commonly referred to. An example of this was found in a case about a 15 year old girl, admitted to a psychiatric clinic on the grounds of her psychological problem:

Based on the report from (the psychiatric ward) was the social services' proposal for support: a placement at (institution). The need for a place at (institution) was based on (the psychiatric ward's) evaluation that X could not return home. Since the psychiatric ward presently proposes that X can live at home with psychiatric support, the social services' suggested support is no longer valid. Significant for the new evaluation is also that (the mother) no longer asks for help from the social services and that there is a plan from the Child and Youth Psychiatry's side, which entails family work. The case is closed without any further actions being taken.

This excerpt shows that the argumentation about the decision offers no description of how the girl herself is thinking or feeling, neither with regards to her present state of health nor in terms of the on-going arrangements surrounding her. Instead the social worker provides the statements issued by the psychiatric unit, alongside the mother's wish to have no on-going support from social services. This means that the psychiatry unit's assessment of the girl's ill health is assigned prominence.

\subsubsection{No Clear Sender}

At times the arguments from the social services were written in a way that made it unclear as to where the information was being sourced. This was the case, for example, in the social worker's arguments concerning a 16 year old boy, in which the Child and Youth Psychiatric Clinic reported a concern about the boy's general wellbeing.

Recently, $X$ has had an assistant in school, which has been a successful support yielding good results. In order for X to feel good psychologically and to have good relationships, he needs help with his daily activities, i.e. schooling.

In this argument, the boy's need for psychological wellbeing is depicted. There is no referral to his opinions in the presentation, however. Instead, the description about both the boy's situation, as well as his needs, is formulated as an objective truth without a clear sender.

\subsubsection{Reports of Behaviour instead of Voices}

In some cases the social workers referred to the children's behaviour instead of their voices when arguing for well-being of the children. The following case concerns a 14 year old girl, an investigation triggered when her school reports that she is suffering from psychosomatic symptoms.

The investigating social worker has met $X$ three times for conversations. During these conversations, $X$ appears as a social and nice girl who talks with ease. At the same time it is evident that she is difficult to get close to and that she has certain difficulties in talking about her well-being along with her behaviour and her situation [...]. Her behaviour could be explained as a way for her to show how she is feeling, since she has certain difficulties in talking about her emotions […]

In this excerpt, the social worker sets out her opinion, namely that the girl has difficulties in expressing her own views about her health. In setting out her judgement about the girl's ill health, the social worker focusses on the child's behaviour.

\subsection{Reports of Children's Voices}

In those 12 arguments where children's views are presented, the children are between the ages of 8 and 17 years, with a mean age of 13.8 years. Only two children were under the age of 12 . When the children's views come to be presented they are reported in different ways.

\subsubsection{Confirmation of a Previous Statement or Opinion}

In none of the arguments laid out by the social services were children's opinions seen to contradict either the individual social workers or other adult persons' description of their health. Instead, the child's views were described sparingly and were often used to confirm a previous statement or opinion. The following example is about a 17 year old boy for whom the social services have concern about his psychological wellbeing.

$X$ 's psychological health is what worries the most. He overdosed on tablets because of psychological ill health. In order to reach a sustainable change with respect to criminality and substance abuse the key to a better psychological health needs to be found. $X$ describes this himself, and has insight into his ill health.

In the above example, the boy's voice is represented as if it confirmed a previous description, constructed as a statement. What it is exactly that the boy has expressed is not made clear. Thus while the boy may be described as having perceptive insight into his ill health, this may also be understood as confirmation of the social services' initial concerns 
about his ill health.

\subsubsection{Focus on Children's Ability to Give Their View}

Another way of representing children's voices was by including descriptions about their ability to give their views. This can be illustrated by the following example, below, about a 17 year old girl whose school raised concern about the girl's physical health.

One of the social workers has been in contact with $X$ at the social services and in meetings with a youth clinic and with a school counsellor. $X$ is a person who in conversation demonstrates an ability to speak for herself and to stand up for her views. The impression is that she is reflexive, mature and clever. It becomes apparent that $X$ does not feel psychologically well, which is evident through both conversation and through her body language. X has-which is clear in conversation - good insight into her situation and she can articulate this in a concrete way[... ]X's psychological ill health also affects other areas of her life, such as school. X has demonstrated a high level of truancy and she says she lacks motivation and energy for school because of conditions at home.

Even though the social worker refers to the girl's view about the posited relation between the cause (home situation) and the problematic behaviour (truancy) the main focus is on her ability to describe her situation and her personal attributes. A description that specifies the girl's mental condition as a contributing factor is also claimed before the girl's views are themselves presented.

\subsubsection{Details about the Child's View}

Two of the cases go into greater detail about what the children actually have said about their health than in the other reports. Nonetheless, even in these examples, support for the decision made by social services comes from the views of other persons as well. The following example, in which a child's voice is given more space than in the aforementioned cases, concerns a 15 year old girl who no longer lives with her parents. The example differs from all the others, since descriptions from the parental perspective are entirely absent.

$X$ has said that she misses her parents and feels bad without them, and in addition she demonstrates physical and psychological symptoms that support this. X and the school says, amongst other things, that she has lost a lot of weight, she often has stomach and head aches, and she continuously sits and shakes her legs, and has furthermore tried to take her own life twice by overdosing on medicines [... ]. X is depressed, which is becoming all the more evident [... ]. She has on one occasion expressed that she has experienced anxiety, making the connection between this and missing her mum. She has indicated that she wants to get away from her situation through a drug overdose[...] From X's bad and destructive mood, as well as the fact that (the persons with whom X now lives) no longer are able to take responsibility for X's situation, placement cannot wait. X risks hurting herself and is in need of care and protection.

This extract shows how the girl's voice is interwoven with other person's opinions about her health. The child's ill health is described by making the girl's own voice appear both with respect to the cause of her ill health as well as to the consequences it may have. At the same time the girl's perspective is confirmed by descriptions offered by the school staff. Additionally, these descriptions are consistent with the s assessment made by the social worker.

\section{Discussion}

Both in law and in regulations connected to the practices of the social services in Sweden, children are to a great extent being acknowledged as competent individuals. It is, for example, argued that children have a right to make themselves heard and that their opinion should be taken into consideration (SoL 11:10). This can be interpreted as if the social services should strive to accord weight to the children's views in support of their decisions. However, there is no specific legal demand to include children's voices in the argumentation. This lack of demand could be a principal reason to explain the findings in this study, which reveals that social workers may not necessarily represent children's voices about their health when justifying their decision. Instead, the voices of adults, such as parents or school staff, are given more space than the children's own voices. This is in line with previous studies showing that social workers, when writing about children's life situation, mainly describe circumstances from adult's interpretations of children (Egelund, 1997; Hennum, 2011; Mattsson, 2002).

By law and UNCRC, social workers must make an assessment of children's age and maturity (UNCRC 12:1; SoL 11:10). But without certain expertise it can be difficult to evaluate children's capacities related to age. The ways in which social workers represent children's perspectives may thereby be understood from the position of how social workers have interpreted the appropriateness of each specific child's age and maturity. Except from the fact that mainly the voices of teenagers were reported, the age of the child is not specifically highlighted in the arguments explored here. Children's maturity, on the other hand, was ascribed significance through descriptions of the child's ability to speak and to make their voices heard. An argument relating to their personalities was often given - for example, in terms of the child as clever and insightful, or, contrarily, as somebody who is difficult to get close to. Such categorisations of 
children may affect how the reliability of children's views is interpreted (Potter, 1996). Therefore, when children are described as competent and insightful, their views may appear as relevant and credible, and vice versa. Descriptions of a child's inability to speak about their own health may, by the same token, work as legitimation for the social worker's lack of reporting of their voices.

Categorisation of adults may also influence the reliability of their views (Potter, 1996) but this study shows that arguments surrounding adults' abilities to speak of a situation are never made. In contrast to the position of children, this can be interpreted that the ability of the adult informants is not questioned in the same way. When adults are categorised in accordance with their professional title or institution - like teachers and medical experts, for example this further assigns to them both status and trustworthiness (Potter, 1996). Aside from the categorisations of individuals, the very language used can also affect how something is understood (Potter, 1996). In those few cases where children's views were represented the descriptions were usually vague and their participation generally low in the arguments presented by the social workers. Descriptions contain few details about the child's opinion. Instead, the representation of a child's views was often used in order to simply confirm a previous statement or opinion by another person. At times children's health, its causes and consequences could be described through statements that were not ascribed to a specific person. Such descriptions may appear as unproblematic objective facts (Potter, 1996). However, statements without an assigned sender do not permit us to know anything about how the child would have described the stated issue with their own words. Nor does it happen that children's voices are represented as differing from, or questioning, the social worker's or other adults' descriptions. Moreover, the social workers were at times focusing on children's performances and behaviours. The implication being that social workers' justifications for their decisions might rely more upon their own subjective interpretation of children's performance rather than giving due weight to children's views about how they experience their health. Besides, if social workers assess children's personal competence based on conversations with them it is of great importance to understand their performance in relation to what opportunities they are provided via the interviewing technique adopted (Cederborg, 2010). Indeed, under the right conditions, children can tell about difficult experiences and perceptions already from the age of 4 (Lamb, Sternberg \& Esplin, 1995; 1998; Winter, 2010).

That arguments are constructed in accordance with the findings from this study may be that social investigations belong to a specific and special text genre. Arguments surrounding the needs of vulnerable children might, from the perspective of social services, be seen as a difficult task to solve, since there are many aspects to consider (such as legal requirements and recommendations as well as established administrative rules of how to argue for possible decision). Furthermore, while such texts should be addressed to the client, at the same time they must be seen to be credible in legal and juridical contexts (Hall, 1997). Finally, there is an argument that children should not be attributed too much responsibility in decision making (National Board of Health and Welfare, 1997) and social workers must also take into account the parents' rights to make decisions concerning their own children (Parental Code 1949:381 [FB] 6:11). All this may have influenced the ways in which children's voices are represented in reports written by the social services. Nevertheless, to be able to understand a child's behavior, development and needs, it is insufficient to receive only information from those adults surrounding the child (Bronfenbrenner, 1979; Meadows, 2010; Rutter \& Taylor, 2002; Woodhead, 1997). Furthermore, decisions about intervention can be difficult to carry through if these decisions are not adjusted to children's wishes and expectations. Children's inclusion in the decision- making process can also increase their sense of well-being (Vis, Strandbu, Holtan \& Thomas, 2011). Children themselves may also wish to be included when decisions concerning their life and their health care are made (Kilkelly \& Donelly, 2011; Leeson, 2007; Mason, 2008). This means that the findings from this study indicate that individual children's views may be excluded in social workers' arguments about children's health needs, thus diminishing the chances of offering effective support.

A limitation with this study is that we do not know if the children's views and wishes about their own health are taken into account while not being directly reported. It may also be possible that the social worker chooses to omit the child's views in order to protect him or her. On balance, however, we conclude that it may be necessary to include the representation of the child's own voice in arguments for decisions as the inclusion can make it clearer how they experience their health situation and if their own experiences of the identified health problem is given due weight in the arguments about their needs.

\section{References}

Alanen, L. (1994). Gender and Generation: Feminism and the "Child Question". In J. Qvortrup, M. Bardy, G. Sgritta, \& H. Wintersberger (Eds.), Childhood Matters (pp. 27-42). Avebury, UK:Aldershot.

Andershed, H., Andershed, A-K., \& Tuvblad, C. (2013). Psykologiska och biologiska perspektiv på sociala anpassningsproblem [Psychological and biologicalperspectives on social problems of adjustment]. In A. Meuwisse, \& H. Swärd (Eds.), Perspektiv på Sociala Problem [Perspectives on social problems]. (2nd ed) (pp.242-260). Stockholm: Natur och Kultur. 
Andersson, G., Aronson, K., Hessle, S., Hollander, A., \& Lundström, T. (2001). Inledning [Introduction]. In K. Aronson (Ed.), Haverier i social barnavård? Fem fallstudier [Breakdowns in child welfare? Five case studies](pp. 9-21). Stockholm, Sweden: Förlagshuset Gothia.

Bronfenbrenner, U. (1979). The Ecology of Human Development. Cambridge, MA: Harvard University Press.

Cederborg, A-C., \& Karlsson, Y. (2001). Omhändertagande med barnets perspektiv [Being taken intocare from the child'sperspective]. Socialvetenskaplig Tidskrift, 3, 163-179.

Cederborg, A-C. (2010). Att intervjua barn. Vägledning för socialsekreterare [Interviewingchildren.Guidelines for social workers]. Stockholm: Stiftelsen Allmänna barnhuset.

Egelund, T. (1997). Beskyttelse av barndommen. Socialforvaltningersrisikovurdering och indgrep. Köpenhamn, DK: Hans Rietzel.

Gallagher, M., Smith, M., Mark, H., \& Wilkinson, H. (2012). Children and Families' Involvement in Social Work Decision Making. Children \& Society, 26(1), 74-85. http://dx.doi.org/10.1111/j.1099-0860.2011.00409.x

Garralda, M. E. (1994). Chronic Physical Illness and Emotional Disorder in Childhood.Where the brain's not involved, there may still be problems. British Journal of Psychiatry, 164, 8-10. http://dx.doi.org/10.1192/bjp.164.1.8

Gironda, M. W., Der-Martirosian, C., Abrego, M., Black, E., Leathers, R., \& Atchison, K.A. (2006). A Qualitative Study of Hardiness and Social Support Among Underserved, Inner- City Minority Adults Recovering from Oral Surgery. Social Work in Health Care, 43(4), 29-51. http://dx.doi.org/10.1300/J010v43n04_03

Gleason, T. R., \& Evans, M. E. (2004). Perceived vulnerability: a comparison of parents and children. Journal of Child Health Care, 8(4), 279-287. http://dx.doi.org/10.1177/1367493504047318

Hall, C. (1997). Social work as narrative.Storytelling and persuasion in professional texts. Aldershot, UK: Ashgate Publishing Ltd.

Heinonen, T., Metteri, A., \& Leach, J. (2009). Applying health determinants and dimensions in social work practice. European Journal of Social Work, 12(2), 139-153. http://dx.doi.org/10.1080/13691450802567424

Hennum, N. (2011). Controlling children's lives: covert messages in child protection service reports. Child and Family Social Work, 16(3), 336-344. http://dx.doi.org/10.1111/j.1365-2206.2010.00744.x

Hollander, A. (2001). En mammas motstånd - om samtycke vid ett omhändertagande [A mother'sresistance - on consentingtocompulsorycare]. In K. Aronson (Ed.), Haverieri social barnavård?Fem fallstudier [Breakdowns in child welfare? Five case studies](pp. 102-138). Stockholm, Sweden: Förlagshuset Gothia.

Hultman, E., \& Cederborg, A-C.(2013). How social workers portray children's perceptions when constructing their identities. International Journal of Social Science Studies, 1(2), 73-81.

James, A., Jenks, C., \& Prout, A. (1998). Theorizing Childhood. Cambridge, UK: Polity Press.

James, A., \& Prout, A. (Eds.). (1997). Constructing and reconstructing childhood: contemporary issues in the sociological study of childhood. (2nd ed). New York: Routledge Falmer.

Kilkelly, U., \& Donelli, M. (2011). Participation in Healthcare: the Views and Experiences of Children and Young People. International Journal of Children's Rights, 19, 107-125. http://dx.doi.org/10.1163/157181810X522379

Lamb, M. E., Sternberg, K. J., \& Esplin, P. W. (1995). Making children into competent witnesses: Reactions to the amicus brief. In Re Michaels: Psychology, Public Policy, and the Law, 1, 438-449.

Lamb, M. E., Sternberg, K. J., \& Esplin, P.W. (1998) Conducting investigative interviews of alleged sexual abuse victims. Child Abuse \& Neglect, 22, 813-823.

Leeson, C. (2007). My life in care: experiences of non-participation in decision-making processes. Child and Family Social Work, 12, 268-277. http://dx.doi.org/10.1111/j.1365-2206.2007.00499.x

Leviner, P. (2011). Rättsliga dilemman i socialtjänstens barnskyddsarbete. [The Legal Dilemmas Inherent in the Child Protection Work of the Social Services].Stockholm, Sweden: Jure. Dissertation.

Ljung, T., \& Friberg, P. (2004).Stressreaktionernasbiologi [The biology of stress reactions]. Läkartidningen, 12(101), 1089-1094.

Lundberg, O., Åberg Yngwe, M., Kölegård Stjärne, M., Björk, L., \& Fritzell, J. (2008). The Nordic experience: welfare states and public health (NEWS). Stockholm: Stockholm universitet/KarolinskaInstitutet, Centre for Health Equity Studies (CHESS).

Mason, J. (2008). A Children's Standpoint: Needs in Out-of-Home Care. Children and Society, 22, 358-369. 
http://dx.doi.org/10.1111/j.1099-0860.2007.00115.x

Mattsson, T. (2002). Barnet ochrättsprocessen. Rättssäkerhet, integritetssyddochautonomiisamband med beslutomtvångsvård [The Child in Statutory Care Proceedings - Legal Security, Protection of Personal Integrity and Autonomy in Connection with Decisions on Statutory Care]. Lund, Sweden: Juristförlaget. Dissertation.

Meadows, S. (2010). The Child as Social person. London: Routledge

National Board of Health and Welfare (Socialstyrelsen). (1997). Barnet i främsta rummet. FN:s konvention om barnets rättigheter förverkligas $i$ Sverige. [The child as the primary consideration. The implementation of The United Nations's convention on the rights of the child] (SOU 1997:116). Stockholm, Sweden: Socialstyrelsen.

National Board of Health and Welfare (Socialstyrelsen). (2006). Barn och unga i socialtjänsten- Utreda, planera och följa upp beslutade insatser.[Children and Youth in Social Services: Investigating, Planning and Monitoring Interventions]. Stockholm, Sweden: Socialstyrelsen.

National Board of Health and Welfare (Socialstyrelsen). (2012). Dokumentation av barnets bästa inom socialtjänsten. [Documentation of the child's best in social services ] Stockholm, Sweden: Socialstyrelsen.

Park, K., Kersey, M., Geppert, J., Story, M., Cutts, D., \& Himes, J. H. (2009). Household food insecurity is a risk factor for iron-deficiency anaemia in a multi-ethnic, low-income sample of infants and toddlers. Public Health Nutrition, http://dx.doi.org/10.1017/S1368980009005540

Potter, J. (1996). Representing reality. Discourse, rhetoric and social construction. London, UK: Sage Publication.

Potter, J. (2003). Discourse analysis and discursive psychology. In P.M. Camic, J.E. Rhodes, \& L. Yardley (Eds.), Qualitative research in psychology: Expanding perspectives in Methodology and design (pp. 73-94). Washington DC, US: American Psychological Association.

Potter, J. (2005). Making psychology relevant. Discourse \& Society, 16(5), 739-747. http://dx.doi.org/10.1177/0957926505054944

Potter, J., \& Wetherell, M. (1987). Discourse and social psychology. Beyond attitudes and behavior. London, UK: Sage Publication.

Potter, J., \& Wetherell, M. (1995). Discourse Analysis. In J.A. Smith, R. Harré, \& L. Van Langenhove (Eds.), Rethinking Methods in Psychology (pp. 80-92). London, UK: Sage Publication.

Power, C., \& Kuh, D. (2006).Life course development in unequal health. In J.S. Siegrist, \& M. Marmot (Eds.), Social inequalities in health. New evidence and policy implications (pp.27-53). New York: Oxford University Press.

Rangel, L., Garralda, M.E., Hall, A., \& Woodham, S. (2003). Psychiatric adjustment in chronic fatigue syndrome of childhood and in juvenile idiopathic arthritis. Psychological Medicine, 33(2), 289-297. http://dx.doi.org/10.1017/S0033291702006529

Robertson, A., Brunner, E., \& Sheiham, A. (2006). Food is a political issue. In M. Marmot, \& R.G Wilkinson (Eds.), Social determinants of health. (2nd ed) (pp. 172-195). New York: Oxford University Press.

Rutter, M., \& Tylor, E. (2002).Clinical assessments and diagnostic formulation. In M. Rutter, \& E. Taylor (Eds.), Child and adolescent psychiatry (pp.18-31) (4th ed). Chichester: Blackwell Publishing.

Sarafino, E.P. (2006). Health psychology. Biopsychosocialinteractions (5th ed). New York: John Wiley \& Sons.

Shaw, M., Dorling, D., \& Smith, G.D. (2006). Poverty, social exclusion and minorities. I M. Marmot, \& R.G. Wilkinson (Eds.), Social determinants of health (2nd ed) (pp. 196-223). New York: Oxford University Press.

Sundell, K., Egelund T., Andrée Löfholm, C., \& Kaunitz, C. (2008). Barnavårdsutredningar: en kunskapsöversikt. [Child protection investigations: a knowledge overview]. Stockholm, Sweden: Gothia

Thomas, N. (2002). Children, family and the state: decision-making and child participation. Bristol, UK: Policy press.

Thomas, N., \& O'Kane, C. (1999). Children's participation in reviews and planning meetings when they are looked after in middle childhood. Child and Family Social work, 4(3), 221-230. http://dx.doi.org/10.1046/j.1365-2206.1999.00112.x

Vis, S.A., Strandbu, A., Holtan, A., \& Thomas, N. (2011). Participation and health- a research review of child participation in planning and decision-making. Child and Family Social Work, 16(3), 325-335. http://dx.doi.org/10.1111/j.1365-2206.2010.00743.x

Wan, J.J., Morabito, D. J., Khaw, L., Knudson, M. M., \& Dicker, R. A. (2006). Mental illness as an independent risk factor for unintentional injury and injury recidivism. Journal of Trauma, 61(6), 1299-1304. 
Winter, K. (2010). The perspectives of young children in care about their circumstances and implications for social work practice. Child and Family Social Work, 15(2), 186-195. http://dx.doi.org/10.1111/j.1365-2206.2009.00658.x

Woodhead, M. (1997). Psychology and the cultural construction of children's needs. In A. James, \& A. Prout (Eds.), Constructing and reconstructing childhood: contemporary issues in the sociological study of childhood (2nd ed ) (pp.63-84). New York: Routledge Falmer.

Law texts

Parental Code (FB) 1949:381

Social Service Act (SoL) 2001:453

Special provisions for Care of Young People Act (LVU) 1990:52

UN Convention on the Rights of the Child (UNCRC)

\section{$(\mathrm{cc}) \mathrm{EY}$}

This work is licensed under a Creative Commons Attribution 3.0 License. 